\title{
Pelatihan Budidaya Sayur Organik Dan Tanaman Herbal Organik Berbasis Teknik Hidroponik
}

\author{
Fitri Handayani \\ Akademi Farmasi Samrinda \\ sausanrukan@yahoo.co.id \\ Sapri \\ Akademi Farmasi Samrinda \\ sapri.juli86@gmail.com \\ Achmad Kadri Ansyori \\ Akademi Farmasi Samrinda \\ achmad.kadri.ansyori@yahoo.co.id
}

\begin{abstract}
Abstrak
Pelatihan ini dilaksanakan dengan memberdayakan masyarakat khususnya ibu rumah tangga yang bertempat tinggal di sekitar J1. Abdul Wahab Sjahranie gang 10 RT 26, Kelurahan air hitam Kecamatan Samarinda Ulu untuk berpartisipasi aktif. Pelatihan dilaksanakan pada hari Jumat tanggal 27 Desember 2017 pukul 13.00 sampai selasai. Metode pelatihan budidaya ini dengan melakukan penyuluhan kepada peserta tentang bercocok tanam dengan teknik hidroponik dan memberikan demonstrasi serta praktek bercocok tanam dengan teknik hidroponik. Peserta dibagi menjadi tiga kelompok masyarakat. Setiap kelompok akan diberikan bibit sayuran dan tanaman hebal untuk dibudidayakan dengan teknik hidroponik. Kelompok pertama adalah kelompok yang diberikan bibit bayam merah, kelompok dua diberikan bibit pakcoy dan kelompok tiga diberikan bibit kangkung. Pada hari pertama masing-masing kelompok melakukan penyemaian bibit ke dalam media tanam rockwool. Pada hari kedua sampai hari ke lima dilakukan penyiraman bibit dengan larutan nutrisi hidroponik. Hari keenam setiap kelompok melakukan penanaman benih ke tempat yang lebih besar. Setiap kelompok melakukan penyiraman larutan nutrisi hidroponik sampai hari ke tiga puluh. Sayuran dan tanaman herbal yang telah tumbuh menjadi besar maka dilakukan pemanenan.
\end{abstract}

Kata Kunci : sayur, tanaman herbal, hidroponik, pelatihan 


\section{Jurnal Abdimas Mahakam \\ https://journal.uwgm.ac.id/index.php/abdimasmahakam \\ Online ISSN : 2549-5755 \\ Januari 2018, Vol. 2 No. 1}

\section{Pendahuluan}

Sayur organik merupakan salah satu sumber nutrisi yang dibutuhkan oleh manusia. Ada beberapa kandungan gizi pada sayur yang tidak terdapat pada sumber bahan makanan lain. Sayur mengandung banyak serat yang memiliki banyak peranan dalam proses pencernaan. Serat dapat melancarkan perncernaan serta dapat mencegah dan mengurangi resiko timbulnya beberapa penyakit (Jahari dan Sumarno, 2001). Tanaman herbal juga merupakan tanaman berkhasiat secara alami, jika diolah dapat bermanfaat dalam meningkatkan kesehatan manusia.

Upaya peningkatan konsumsi sayuran dan tanaman herbal perlu dilakukan untuk memenuhi kebutuhan serat dan nutrisi lain bagi tubuh manusia. Selain itu, hal tersebut perlu diimplementasikan pada masyarakat luas agar masyarakat mengerti akan pentingnya konsumsi sayur dan tanaman herbal dalam menjaga kesehatan.

Jumlah lahan pertanian khususnya di daerah perkotaan semakin berkurang. Hal ini dikarenakan lahan di perkotaan lebih banyak dimanfaatkan untuk pemukiman dan pusat-pusat pertokoan. Hidroponik merupakan salah satu sistem pertanian masa depan karena dapat diusahakan diberbagai tempat baik di desa, kota, lahan terbuka atau di atas apartemen sekalipun. Luas tanah yang sempit, kondisi tanah kritis, hama dan penyakit yang tak terkendali, keterbatasan jumlah air irigasi, musim yang tak menentu dan mutu yang tidak seragam bisa ditanggulangi dengan sistem hidroponik. Hidroponik dapat diusahakan sepanjang tahun tanpa mengenal musim. Pemeliharaan tanaman hidroponik pun lebih mudah karena tempat budidayanya relatif bersih, media tanamnya steril, serangan hama dan penyakit relatif kecil, serta tanaman lebih sehat dan produktivitasnya lebih tinggi (Hartus, 2008). Tanaman yang cocok ditanaman dengan teknologi ini adalah tanaman sayuran berdaun seperti selada, bayam, kangkung dan sebagainya, sedangkan tanaman herbal yang cocok dengan hidroponik yaitu, sirih, jahe, daun dewa, dan tanaman daun herbal lainnya. 


\section{Jurnal Abdimas Mahakam \\ https://journal.uwgm.ac.id/index.php/abdimasmahakam \\ Online ISSN : 2549-5755 \\ Januari 2018, Vol. 2 No. 1}

Budidaya sayur organik dan tanaman herbal merupakan kombinasi yang dapat bermanfaat bagi masyarakat sekitar Akademi Farmasi Samarinda dalam meningkatkan ekonomi dan kesehatan masyarakat sekitar.

Tujuan pelatihan budidaya sayur organik dan tanaman herbal organik berbasis teknik hidroponik ini adalah sebagi berikut :

1. Memperkenalkan budidaya menggunakan metode bercocok tanam dengan teknik hidroponik kepada masyarakat.

2. Menyiasati penggunaan lahan sempit untuk bercocok tanam sayuran dan tanaman herbal.

3. Meningkatkan konsumsi sayuran dan tanaman herbal untuk memenuhi kebutuhan serta dan nutrisi tubuh manusia.

\section{Metode}

Pelatihan ini dilaksanakan dengan memberdayakan masyarakat setempat untuk berpartisipasi aktif. Metode pelatihan budidaya ini dengan melakukan penyuluhan kepada masyarakat setempat tentang bercocok tanam dengan teknologi hidroponik dan memberikan pelatihan bercocok tanam dengan teknologi hidroponik. Pelaksanaan pelatihan diawali dengan tahapan sebagai berikut :

1. Persiapan

Persiapan pelatihan dilakukan sebagai berikut :

a. Melakukan kerjasama dengan masyarakat sekitar Akademi Farmasi Samarinda

Tahap awal yang dilakukan adalah melakukan musyawarah untuk kerjasama dengan masyarakat setempat yang memiliki pengaruh besar terhadap masyarakat sekitar Akademi Farmasi Samarinda. Musyawarah ini akan disampaikan maksud dan tujuan dari pelatihan budidaya serta meminta izin merealisasikan pelatihan ini di kawasan tersebut. Selain itu, disampaikan teknis kegiatan yang akan dilakukan yaitu berupa sosialisasi langsung ke masyarakat melalui poster, brosur, penyuluhan dan penanaman dengan teknik hidroponik. 


\section{Jurnal Abdimas Mahakam \\ https://journal.uwgm.ac.id/index.php/abdimasmahakam \\ Online ISSN : 2549-5755 \\ Januari 2018, Vol. 2 No. 1}

b. Persiapan alat dan bahan

Tahap selanjutnya yang akan dilakukan adalah menyiapkan alat dan bahan yang akan digunakan untuk menanam sayuran dan tanaman herbal. Alat dan bahan yang perlu disiapkan diantaranya adalah media tanam rockwool, netpot, kain flanel, botol plastik, gelas ukur, gunting, pisau cutter, bibit sayuran dan tanaman herbal, nutrisi hidroponik dan air.

c. Menyusun rundown acara

Pelatihan dilaksanakan pada hari Jumat tanggal 27 Desember 2017 pukul 13.00 sampai selasai. Acara pelatihan diawali dengan pembukaan acara, pemberian materi, demonstrasi teknik hidroponik dan penutup.

d. Menentukan materi penyuluhan

Materi yang akan diberikan kepada masyarakat adalah mengenai bercocok tanam dengan teknik hiroponik yang meliputi penyemaian benih, penanaman benih yang telah tumbuh, perawatan sayuran dan tanaman herbal dan pemanenan, sayuran dan tanaman herbal apa saja yang bisa ditanam, apa keuntungan yang bisa diperoleh dari proses bercocok tanam dengan teknik hiroponik.

e. Perijinan

Mengurus perijinan waktu dan tempat pada ketua RT 26, Kelurahan air hitam Kecamatan Samarinda Ulu.

\section{Pelaksanaan}

Langkah awal yang dilakukan yaitu warga sekitar Jl. Abdul Wahab Sjahranie gang 10 RT 26, Kelurahan air hitam Kecamatan Samarinda Ulu beserta tokoh masyarakat setempat mengumpulkan sejumlah warga di salah satu rumah warga yang dipilih atau yang tempat memungkinkan melakukan pelatihan. Kegiatan yang akan dilakukan adalah sosialisasi berupa penyuluhan yang menyangkut tentang penyemaian bibit, penanaman bibit yang telah tumbuh, perawatan, dan pemanenan, tanaman apa saja yang bisa ditanam, apa keuntungan yang bisa 


\section{Jurnal Abdimas Mahakam \\ https://journal.uwgm.ac.id/index.php/abdimasmahakam \\ Online ISSN : 2549-5755 \\ Januari 2018, Vol. 2 No. 1}

diperoleh dari proses bercocok tanam dengan teknik hiroponik serta tips dan trik menanam dengan teknik hidroponik oleh narasumber. Selain pemberian materi teknik hidroponik, masyarakat juga dapat melihat dan mempraktekkan secara langsung demonstrasi penanaman tanaman dengan teknik hiroponik. Peserta pelatihan ini dibagi menjadi tiga kelompok masyarakat. Setiap kelompok akan diberikan bibit sayuran dan tanaman hebal untuk dibudidayakan dengan teknik hidroponik.

\section{Hasil dan Pembahasan}

Pelatihan budidaya sayur organik dan tanaman herbal organik dengan teknik hidroponik dilakukan pada kelompok masyarakat khususnya ibu rumah tangga yang bertempat tinggal di sekitar J1. Abdul Wahab Sjahranie gang 10 RT 26, Kelurahan air hitam Kecamatan Samarinda Ulu.

Selama pemberian materi teknik hidroponik, peserta pelatihan sangat antusias. Antusias peserta ini dapat dilihat pada berbagai pertanyaan peserta yang banyak mulai dari pertanyaan bagaimana membudidayakan sayuran dan tanaman herbal dengan lokasi yang sempit sampai bagaimana sayuran dan tanaman herbal bisa dijadikan sumber pendapatan bagi peserta. Pemberian materi budidaya sayur dan tanaman herbal dapat dilihat pada gambar 1 .
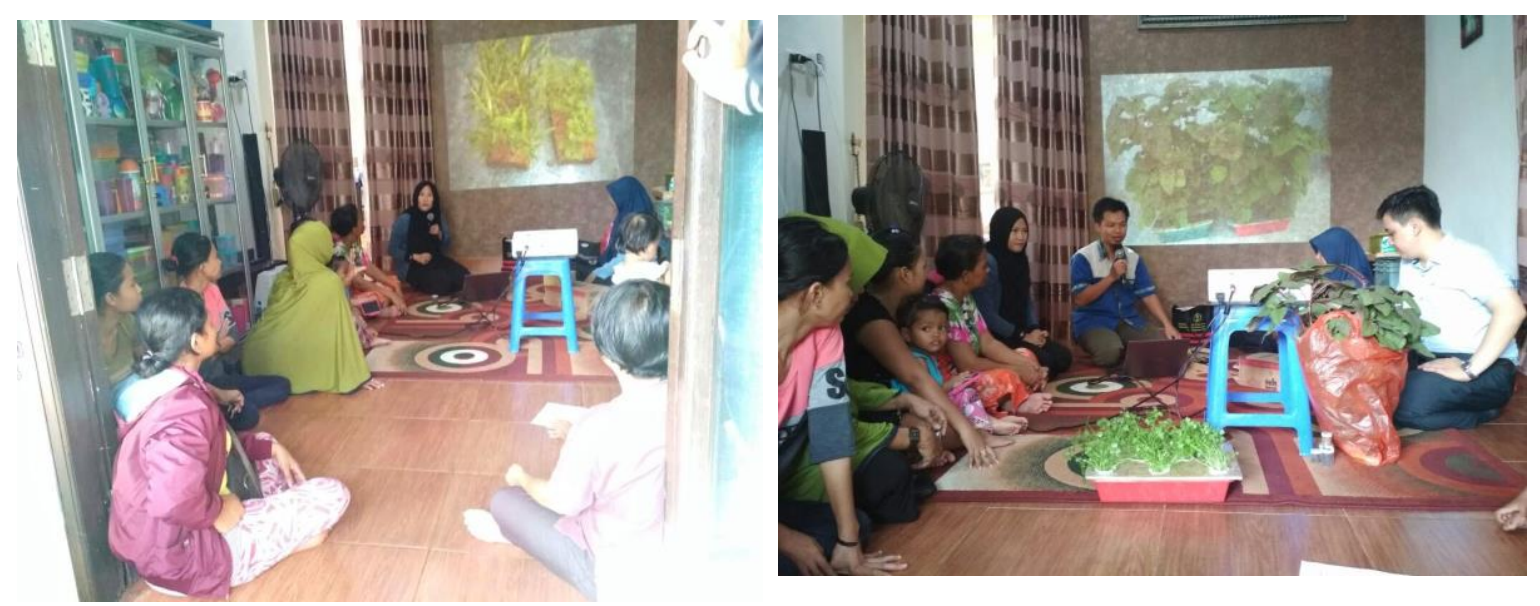

Gambar 1. Pemberian Materi Budidaya Sayur Organik dan Tanaman Herbal Organik Berbasis Teknik Hidroponik 


\section{Jurnal Abdimas Mahakam \\ https://journal.uwgm.ac.id/index.php/abdimasmahakam \\ Online ISSN : 2549-5755 \\ Januari 2018, Vol. 2 No. 1}

Setiap kelompok peserta pelatihan diberikan bibit sayuran dan tanaman herbal, media tanam rockwoll dan serbuk nutrisi hidroponik untuk dibudidayakan dengan teknik hidroponik. Setiap kelompok diajarkan cara menyiapkan media tanam dan cara membuat larutan nutrisi hidroponik untuk penyiraman bibit sayuran dan tanaman herbal yang akan tumbuh.
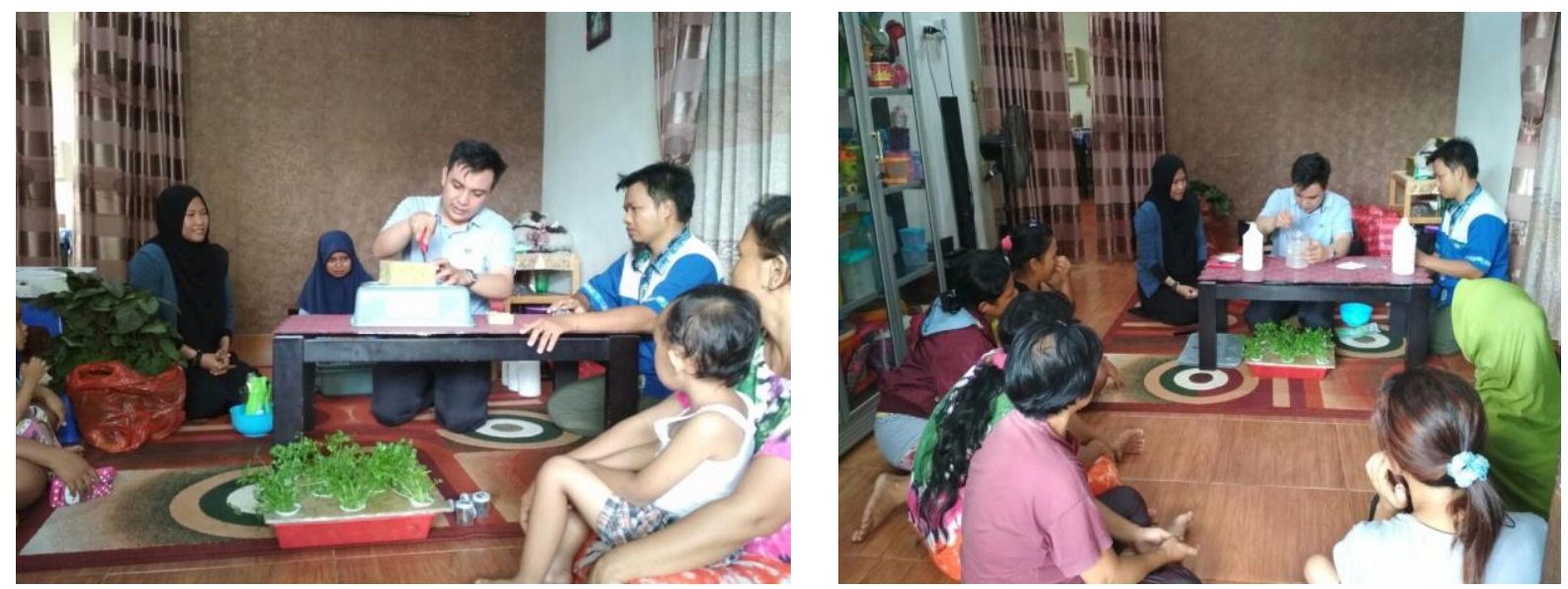

Gambar 2. Demonstrasi Persiapan Media Tanam Rockwool dan Pembuatan Larutan Nutrisi Hidroponik

Masing-masing kelompok pelatihan terdiri dari 3 orang. Kelompok pertama adalah kelompok yang diberikan bibit bayam merah, kelompok dua diberikan bibit pakcoy dan kelompok tiga diberikan bibit kangkung. Pada hari pertama masing-masing kelompok melakukan penyemaian bibit ke dalam media tanam rockwool. Penyemaian masing-masing kelompok dapat dilihat pada gambar 3. Pada hari kedua sampai hari ke lima dilakukan penyiraman bibit dengan larutan nutrisi hidroponik. Hari keenam setiap kelompok melakukan penanaman benih ke tempat yang lebih besar. Setiap kelompok melakukan penyiraman larutan nutrisi hidroponik sampai hari ke tiga puluh. Sayuran dan tanaman herbal yang telah tumbuh menjadi besar maka dilakukan pemanenan. 


\section{Jurnal Abdimas Mahakam \\ https://journal.uwgm.ac.id/index.php/abdimasmahakam \\ Online ISSN : 2549-5755 \\ Januari 2018, Vol. 2 No. 1}

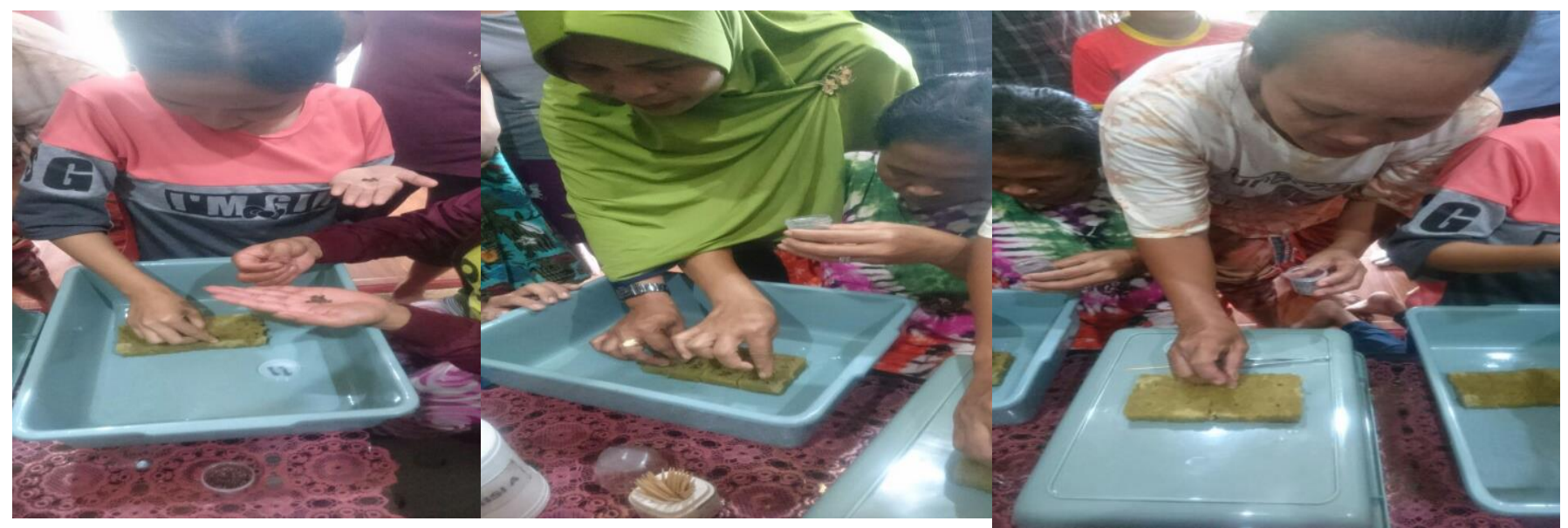

Kelompok 1

Kelompok 2

Kelompok 3

Gambar 3. Penyemaian bibit ke dalam media tanam Rockwoll

Setiap minggunya masing-masing kelompok secara rutin melaporkan perkembangan pertumbuhan sayuran dan tanaman herbal yang ditanam. Kunjungan dan pengontrolan kelompok dalam budidaya sayuran dan tanaman herbal teknik hidroponik ini dilakukan sekali dalam seminggu. Pada hari ke tiga puluh menunjukkan pertumbuhan sayuran dan tanaman herbal yang besar dan siap untuk dipanen. Hasil pertumbuhan sayuran dan tanaman herbal dapat dilihat pada gambar 4 . 


\section{Jurnal Abdimas Mahakam \\ https://journal.uwgm.ac.id/index.php/abdimasmahakam \\ Online ISSN : 2549-5755 \\ Januari 2018, Vol. 2 No. 1}

Pakcoy Bayam Merah

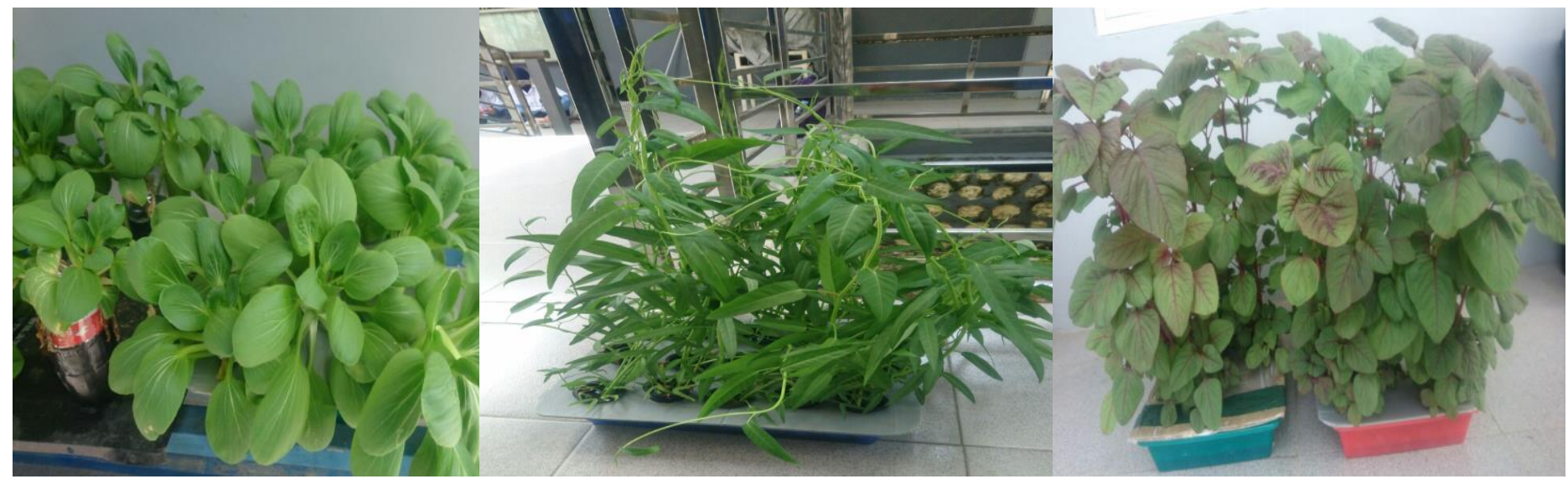

Kangkung

Gambar 4. Hasil Pelatihan Budidaya Sayuran dan Tanaman Herbal Organik Teknik Hidroponik

Tanaman hidroponik bisa dilakukan skala skecil di rumah sebagai suatu hobi ataupun secara besar-besaran dengan tujuan komersial. Beberapa kelebihan tanaman hidroponik antara lain ramah lingkungan, hemat air karena penggunaan air hanya 1/20 dari tanaman biasa, dan mengurangi $\mathrm{CO} 2$ karena tidak perlu menggunakan kendaraan atau mesin. Tanaman hidroponik tidak merusak tanah karena tidak menggunakan media tanah dan juga tidak membutuhkan tempat yang luas. Lebih hemat waktu dan tenaga karena tidak perlu menyiramkan air setiap hari. Pertumbuhan tanaman lebih cepat dan kualitas hasil tanaman dapat terjaga. Dapat tanam di mana saja bahkan di garasi dan tanah yang berbatu dan dapat ditanam kapan saja karena tidak mengenal musim.

Menggunakan cara hidroponik hasil panen akan lebih jauh melimpah dan berlipat ganda sebab tidak ada hasil panen yang dibuang karenan teknik hidroponik ini membuat tanaman lebih steril dan bersih. Pada hasil panen yang menggunakan media tanam biasanya memerlukan teknik sortir pada saat panen jadi di pilah-pilah antara kondisi tanaman yang baik dan tidak. Untuk tanaman yang kondisinya buruk itu sangat kecil sekali sebab kelebihan dari teknik ini adalah tidak mudah terserang hama, gulma dan penyakit. 


\section{Jurnal Abdimas Mahakam \\ https://journal.uwgm.ac.id/index.php/abdimasmahakam \\ Online ISSN : 2549-5755 \\ Januari 2018, Vol. 2 No. 1}

Hasil panen dengan menggunakan teknik hidroponik lebih renyah dan bergizi sebab teknik hidroponik bebas dari pestisida sehingga sangat sehat dikonsumsi. Teknik hidroponik juga tidak membuat tanaman bergantung pada iklim sehingga meski hujan ataupun kemarau tanaman dapat tumbuh dengan baik sehingga resiko terjadinya kerusakan pada tanaman lebih sedikit.

\section{Simpulan dan Rekomendasi}

1. Peserta pelatihan memiliki tambahan wawasan tentang metode bercocok tanam dengan teknik hidroponik

2. Peserta pelatihan mendapatkan ilmu tambahan mengenai pemanfaatan lahan sempit daerah perkotaan untuk bercocok tanam sayuran dan tanaman herbal secara kreatif sebagai peluang berwirausaha.

3. Peserta pelatihan secara kontinue membudidayakan sayuran dan tanaman herbal dengan teknik hidroponik sebagai motivasi untuk meningkatkan konsumsi sayuran dan tanaman herbal. 


\section{Jurnal Abdimas Mahakam \\ https://journal.uwgm.ac.id/index.php/abdimasmahakam \\ Online ISSN : 2549-5755 \\ Januari 2018, Vol. 2 No. 1}

\section{Daftar Pustaka}

Jahari, AB, Sumarno, I (2001). Epidemiologi konsumsi Serat di Indonesia. Bogor. Gizi Indonesia.

Hartus, T (2008). Berkebun Hidroponik Secara Murah Edisi IX. Jakarta. PT. Agromedia Pustaka.

Fitriana, R., Nur, D. R., \& Arbain, A. (2017). Pelatihan dan Simulasi IELTS bagi Mahasiswa dan Dosen di Lingkungan Fakultas Pendidikan dan Keguruan Program Studi Bahasa Inggris Universitas Widya Gama Mahakam Samarinda. Jurnal Abdimas Mahakam, 1(2), 88-95. 